\title{
APPLICATION OF FUZZY ANALYTIC HIERARCHY PROCESS TO BUILDING RESEARCH TEAMS
}

\author{
Karol DĄBROWSKI, Katarzyna SKRZYPEK \\ University of Zielona Góra
}

\begin{abstract}
:
Building teams has a fundamental impact for execution of research and development projects. The teams appointed for the needs of given projects are based on individuals from both inside and outside of the organization. Knowledge is not only a product available on the market but also an intangible resource affecting their internal and external processes. Thus it is vitally important for businesses and scientific research facilities to effectively manage knowledge within project teams. The article presents a proposal to use Fuzzy AHP (Analytic Hierarchy Process) and ANFIS (Adaptive Neuro Fuzzy Inference System) methods in working groups building for R\&D projects on the basis of employees skills.
\end{abstract}

Key words: Fuzzy AHP, ANFIS, R\&D Project, knowledge management

\section{INTRODUCTION}

For some time now businesses as well as scientific research units have been faced with the challenge to adapt their operations to the needs of knowledge economy. The expectations are high - top quality products and "lean manufacturing", application of technical state of the art, innovation that satisfied and creates market needs. In order to live up to these expectations, businesses and R\&D facilities have to undertake resolute efforts at managing the knowledge they posses. This subject matter is specific in that first and foremost knowledge is not only a product available on the market but also an intangible resource affecting their internal. and external processes. Thus it is vitally important for businesses and scientific research facilities to effectively manage knowledge within project teams.

The teams appointed for the needs of given projects are based on individuals from both inside and outside of the organization It all depends on the type of project and sources of finance, Problems in building an effective team lie not only in selecting people from the outside. Large international corporations with anywhere in between a few hundred to a few thousand workers from different countries and importantly different cultures, also face similar problems. The execution of these projects relies on teamwork. And the correct selection of staff is key to effective performance and results.

This paper focuses on presenting staff selection methods for building research teams for R\&D projects. The presented method outline for their testing is based on fuzzy logic. The method description is preceded by an introduction to research and development project problem set, knowledge management and a general description of the fuzzy analytic hierarchy process method and ANFIS as a support tool in building a research team.

\section{RESEARCH AND DEVELOPMENT PROJECT SPECIFICATION}

James P. Lewis describes a project as a "one-off task, with a defined start time and a completion date, clearly stated objectives scope of activity and (usually) a defined budget" [7]. With reference to literature on the subject an assumption surfaces, that the cause for staring a project is either own need or a typical customer order [13]. The authors of the above project definitions emphasise that the main task of a project is to achieve objectives or a defined result and they do not take into consideration uncertainty and risk inherent in the performance of projects. This means that a general definition of a project should not be applied to research and development projects.

Among the various types of projects the author focuses on describing a research and development project as applicable to the knowledge movement field. The research and development project concept is a broad take on activity entailing the creation of new units and changing those already in existence. There is no one R\&D project definition in general use. However, in literature on the subject a definition of research and development activity may be found. Colloquially this concept is often used as a synonym for a research and development project. This is not always correct.

"Research and development activity is defined as systematic creative works, under-taken to further knowledge (...) as well as to find new applications for the knowledge. It comprises three types of basic research (theory and experimental works in principle not focused on obtaining any given practical applications) and applied (research works undertaken to obtain new knowledge put to use in particular practical applications) and development works (entailing the application of existing knowledge to design new or a significant improvement to existing products, processes or 
services)" [5]. The cited definition is similar to the definition suggested by the OECD in the Frascati manual [12].

Taking into consideration the definition of an R\&D project and activity, the concept of a research and development project may be defined as a business undertaking, constituting a unique task with the following characteristic feature:

- a loosely defined objective which is to be achieved through the performance of works,

- a defined start and a loosely indicated completion date, outlined stages,

- resource hungry: people, finance, material, equipment, etc.

- an organizational structure specific to projects and an organizational independence in terms of other organization operations

- significant innovation,

- large uncertainty, risk and volatility in terms of actual problem solving,

- interdisciplinarity - the projects require specialists from across various disciplines to be engaged $[2,6,11]$.

With reference to the above assumptions one may risk an assertion that such a project is defined as the performance of a certain risk bearing objective which does not require a precise definition, usually resulting in new knowledge on our reality, which we have the resources to achieve including a highly qualified team of contractors a certain time scope and knowledge on the assumed parameters [6].

Project management is the process of performing a predefined research and development project. The popular take on project management is that it is a continual search for reasons for success and sources of failure [3]. Management requires a series of decisions to be made leading to the performance of objectives formulated at the planning stage. "According to management and organization theory, the process of managing research and development projects comprise four primary relations which occur during project design and performance - these are: planning, organizing, motivating and controlling" [6]. Managing research and development projects is considered to be an adaptive and extreme project management method, as $R \& D$ project objectives are not precisely defined during the design stage [15].

In the latter part of the article the author focuses on one project management stage: process organization and in particular finding the human resources required by a research and development project at a production company or a research and development facility.

\section{KNOWLEDGE. MANAGING AND MAKING USE OF POTENTIAL}

Knowledge has certain characteristics, which set it apart from other resources in an organization. "Primarily it is dominant and ever more often decisive when it comes to success. The fact that it is inexhaustible is another one of its characteristic features and as such sharing knowledge does not diminish this resource, but on the contrary, is conducive to exchanging opinions and leads to its growth. Also, it may be used by many individuals at the same time at an organization [10].

The knowledge management concept became a permanent item in scientific papers as well as business growth strategy policy in the 1990s. Pursuant to a theory with some weight formulated within the scope of this discipline is that knowledge is primarily created by group contact and not in the heads of given individuals [4]. This theory confirms the viability of an effective method for selecting participants/those involved with the performance of R\&D projects.

The 1990s the also saw the start of the process associated with Europe driving to become more competitive on the world market. That objective was to be achieved through the creation of a Europe of knowledge or the European Knowledge Economy (KE).

Despite the KE concept being prevalent it is somewhat loosely defined and may be understood in two ways. The narrower understanding of a $\mathrm{KE}$ is an economy comprising many businesses which base its competitive advantage on knowledge. The broader approach is to take into account the roles of physical persons, social organizations and the state in the process of suing and creating knowledge [14].

However, competitive advantage is not guaranteed by possessing knowledge but the ability to apply it to a given situation. As unused knowledge is useless [14]. Thus actions leading to the correct management of resources at hand should be taken.

And as such the subject of this paper is the concept of designing a method for assessing personal criteria weights required for effective research team building. This method treats criteria as a linguistic variable with fuzzy value sets, and it is suggested that these criteria should be tested using fuzzy sets.

\section{THE FAHP METHOD}

The FAHP (Fuzzy Analytic Hierarchy Process) method is based on the AHP method, which is widely used in creating decision models. FAHP uses expert opinions to determine the weight coefficients determining the importance of characteristics and makes it possible to eliminate characteristic with least significance when it comes to the linear ordering concept. In this case weights of characteristics are determined on the basis of fuzzy expert opinions i.e. soft opinions which are more realistic than hard opinions [9].

\section{THE ANFIS SYSTEM}

ANFIS (Adaptive Neuro-Fuzzy Inference System) is the only neuro-fuzzy system of its kind. It is an adaptive neurofuzzy inference system with features equivalent to neurofuzzy systems. The application of this system makes it possible to build a fuzzy model with parameters generated by a neural network [1]. ANFIS is a compilation of a linguistically modified fuzzy inference systems with an the learning abilities of an artificial neural network.

Inference systems are widely applicable. They are used as a research support tool in many disciplines, e.g. in image processing control, geology, global economy, assessment and classification in decision processes and management.

A significant advantage of fuzzy models is that they require much less information about the system as compared to conventional probability models [1]. Furthermore the said information may be somewhat imprecise and fuzzy. Application of the ANFIS system seems to yield results in modelling complex problems where the relations between given model factors are not known.

To proceed with the research the author suggest the use of an adaptive neuro-fuzzy interference system with the Takagi-Sugeno interference model. 


\section{RESEARCH METHODOLOGY}

The procedure for assessing strategic factors in selecting personnel required for the performance of a research and development project is based on a fuzzy analytic hierarchy process, a method used to solve multi-criteria decision problems. The method follows theses stages:

Stage I. Constructing a hierarchical decision chart. This process entails the construction of a hierarchical decision chart comprising a main objective, secondary objectives and tasks. The main objective comprising a number of secondary objectives defining it is at the top of the hierarchy. The next level of the desiccant chart holds tasks the performance of which is required to achieve the secondary objectives. The tasks may also be broken down into secondary actions. The decision chart has a number of levels, the number of which is determined by the level of generality sought by these deliberations. The main objective and secondary objectives should be interrelated.

Stage II. Comparing tasks in pairs within the scope of a secondary objective. The significance between decision elements is compared in pairs applying a fuzzy nine degree scale (Table 1). These comparisons are analysed in terms of weights in the decision process. A scale is used to compare the significance of secondary objectives with reference to the main objective and tasks within the scope of every secondary objective (Table 1). The significance in pairs of factors at every level of the hierarchy is compared by experts (decision-makers) directly associated with the decision process in question.

Results of comparisons are then tabulated as fuzzy pair comparison matrices $\tilde{A}$ :

$$
\tilde{A}=\left[\widetilde{a}_{k g}\right]=\left[\begin{array}{cccc}
(1,1,1) & \left(l_{12}, m_{12}, u_{12}\right) & \ldots & \left(l_{1 p}, m_{1 p}, u_{1 p}\right) \\
\left(l_{21}, m_{21}, u_{21}\right) & (1,1,1) & \ldots & \left(l_{2 p}, m_{2 p}, u_{2 p}\right) \\
\ldots & \ldots & \ldots & \ldots \\
\left(l_{p 1}, m_{p 1}, u_{p 1}\right) & \left(l_{p 2}, m_{p 2}, u_{p 2}\right) & \ldots & (1,1,1)
\end{array}\right],
$$

$$
\tilde{a}_{k g}=\left(l_{k g}, m_{k g}, u_{k g}\right) \tilde{a}_{g k}=\tilde{a}_{k g}{ }^{-1}=\left(1 / u_{k g}, 1 / m_{k g}, 1 / l_{k g}\right), k, g=1,2, \ldots p
$$

and $k \neq g$, $\tilde{a}$ where: are the results of task pairs significance comparisons or geometric means of assessments in a group of experts.

The $\tilde{a}_{\mathrm{kg}}=\left(\mathrm{l}_{\mathrm{kg}}, \mathrm{m}_{\mathrm{kg}}, \mathrm{u}_{\mathrm{kg}}\right)$ is a triangular fuzzy number represented by three assessments: pessimistic $I_{\mathrm{kg}}$, most probable $\mathrm{m}_{\mathrm{kg}}$ and optimistic $\mathrm{u}_{\mathrm{kg}}$.

Stage III. Determining the sum of the elements in each row of the fuzzy pair comparison matrix and normalising row sums using operations on fuzzy numbers:

$$
\begin{gathered}
\widetilde{Q}_{k}=\left(l_{k}, m_{k}, u_{k}\right)=\sum_{g=1}^{p}\left(l_{k g}, m_{k g}, u_{k g}\right) \otimes \\
\otimes\left[\sum_{k=1}^{p} \sum_{g=1}^{p}\left(l_{k g}, m_{k g}, u_{k g}\right)\right]^{-1}, k=1,2, \ldots p
\end{gathered}
$$

Stage IV. Calculating the degree to which it is possible that the $\widetilde{Q}_{k}$ fuzzy number is more than or equal to $\widetilde{Q}_{g}$, or that $\widetilde{Q}_{k} \geq \widetilde{Q}_{g}$ using the following equation:

$$
V=\left(\tilde{Q}_{k}-\tilde{Q}_{g}\right)=\mu_{Q_{k}}(d)=\left\{\begin{array}{cl}
1, & \text { for } m_{k} \geq m_{g} \\
0, & \text { for } l_{g} \geq u_{k} \\
\left(l_{g}-u_{k}\right) /\left(\left(m_{k}-u_{k}\right)-\left(m_{g}-l_{g}\right)\right) & \text { for } \text { others }
\end{array}\right.
$$

where:

$\widetilde{Q}_{k}=\left(I_{k}, m_{k}, u_{k}\right)$ and $\tilde{Q}_{g}=\left(I_{g}, m_{g}, u_{g}\right)$ are two fuzzy numbers and $\mu_{\tilde{Q}_{k}}(d)$ (abscissa of point $D$ the intersection of $\mu_{Q_{k}}$ and $\mu_{\tilde{Q}_{\mathrm{g}}}$ membership functions) is the degree of membership of $d$ in $\tilde{Q}_{k}$ (Figure 1).

Stage V. Finding the lowest truth value $V=\left(\tilde{Q_{k}} \geq \tilde{Q_{g}}\right)$ for the $\widetilde{Q}_{k}$ fuzzy number in relation to all other $(p-1)$ fuzzy numbers as:

$$
V=\left(\widetilde{Q}_{k} \geq \widetilde{Q}_{g}\right) g=1, \ldots, p, k \neq g=\min _{\substack{g=(1, \ldots p) \\ g \neq k}} V\left(\widetilde{Q}_{k} \geq \widetilde{Q}_{g}\right)=
$$

\begin{tabular}{|c|c|c|}
\hline Decision elements more significant & Meaning & $\begin{array}{l}\text { Significance weights } \\
\qquad(\widetilde{a}=(l, m, u))\end{array}$ \\
\hline Equivalent & Both factors equally significant in objective performance. & $\tilde{1}=(1,1,1)$ \\
\hline Low or moderate & Unconvincing significance or low preference of one factor over the other. & $\widetilde{3}=(1,3,5)$ \\
\hline Significant, fundamental high & Fundamental or high preference of one factor over the others. & $\widetilde{5}=(3,5,7)$ \\
\hline Overwhelming or very high & Overwhelming or very high preference of one factor over the other. & $\widetilde{7}=(5,7,9)$ \\
\hline Absolute & Absolute significance or absolute preference of one factor over the other. & $\widetilde{9}=(7,9,9)$ \\
\hline $\begin{array}{l}\text { For compromise comparisons } \\
\text { between the above values }\end{array}$ & $\begin{array}{l}\text { A numerical interpolation of compromise opinions is sometimes required, } \\
\text { as there is no vocabulary to describe them appropriately leading to the } \\
\text { use of intermediary values between two subsequent grades. }\end{array}$ & $\begin{array}{l}\tilde{2}=(1,2,4) \\
\tilde{4}=(2,4,6) \\
\tilde{6}=(4,6,8) \\
\widetilde{8}=(6,8,9)\end{array}$ \\
\hline Transitivity of grades & $\begin{array}{l}\text { If the i'th factor has one of the above degrees assigned to it compared } \\
\text { with the j'th factor, then the j'th factor will have the reciprocal value } \\
\text { when compared with the i'th. }\end{array}$ & $\begin{array}{l}\text { reciprocals of the } \\
\text { above values }\end{array}$ \\
\hline
\end{tabular}

$$
{ }^{\mu} \widetilde{Q}_{k}(d)=\mu \widetilde{Q}_{k}(d), k=1,2, \ldots p
$$

Table 1

Nine degree scale for assessing significance between paired elements 


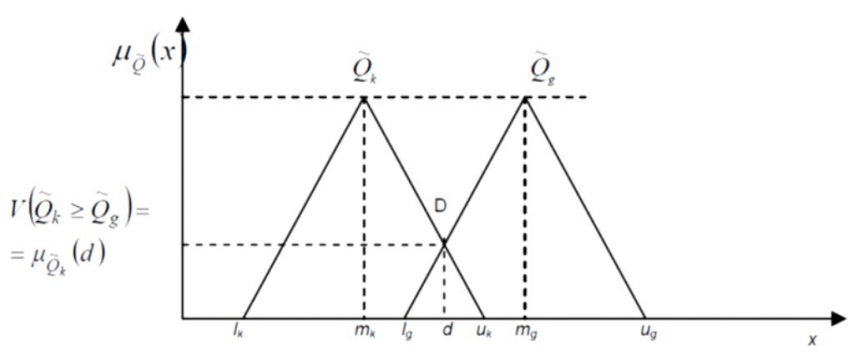

Fig. 1 Finding the intersection coordinates between $\tilde{Q}_{k}$ and $\tilde{Q}_{g}$ Source: [8].

Stage VI. Calculating membership indicators:

$$
\begin{gathered}
w_{k}(l)=V=\left(\widetilde{Q}_{k} \geq \widetilde{Q}_{g}\right) g=1, \ldots p, k \neq g \\
\sum_{h=1}^{p} V\left(\widetilde{Q}_{k} \geq \widetilde{Q}_{g}\right) g=1, \ldots p, k \neq g, k=1,2, \ldots p
\end{gathered}
$$

which are adopted as local weights of tasks. Local priorities (weights) determine relative task significance within the scope of a given secondary objective.

Stage VII. Calculating the values for global priorities. Global task weights represent their significance in terms of the main objective. The sum of all global weights for tasks is 1. They are calculated by multiplying local and global priorities and for secondary objectives $w_{k}=w_{k}^{(1)} \cdot w$. Consequently the $w_{k}$ values are taken to be the global priorities for tasks and is represented in as the $W=\left(w_{1}, w_{2}, \ldots, w_{p}\right)^{\top}$ vector whereas

$$
\sum_{k=1}^{p_{j}} w_{k}=w, w \geq 0 .
$$

Local priorities (weights) for secondary objectives may be calculated analogously following stages II-VI, whereas the local and global weight coefficients for a given secondary objective are identical.

Stage VIII. Application of the ANFIS system. Results analysis begins with selecting the initial structure and fuzzy regulator parameters. The input variable number is entered and system output is determined. Input values are staff competencies and output constitutes a given person.

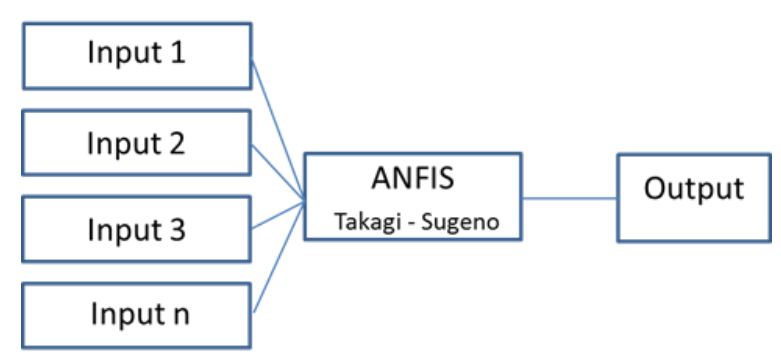

Fig. 2 Model of data implementation

Stage IX. Determining the range and membership function describing the fuzzy set for each input variable. Linguistic variables are defined by three membership functions named low, average and high.

Stage X. Applying the Takagi - Sugeno principle to solve the problem.

If $\left(x_{1}\right.$ is $\left.A_{1}\right)$ and $\left(x_{2}\right.$ is $\left.A_{2}\right)$ and $\ldots$ and $\left(x_{n}\right.$ is $\left.A_{n}\right)$ then $y=f\left(x_{1}, x_{2}, \ldots, x_{n}\right)$

where:

$\mathrm{x}_{1}, \mathrm{x}_{2}, \mathrm{x}_{\mathrm{n}}$ are input variables,

$A_{1}, A_{2}, \ldots, A_{n}$ - fuzzy sets, $\mathrm{y}$ - output variable,

$f\left(x_{1}, x_{2}, \ldots, x_{n}\right)$ - function.

The linguistic model is constructed in such manner, which contains a record of model behaviour. These parameters then generate the output variable, which is our solution $b$ to the problem.

\section{CONCLUSIONS AND FUTURE WORK}

This paper aims to present the problem set associated with the application of fuzzy analytic hierarchy process to building research teams. It attempts to depict this concept in the backdrop of a wider aspect of creating an effective research and development project management tool in an environment where the economy relies on knowledge for its existence.

It was determined that the application of the fuzzy analytic hierarchy process to determine the working team is possible for many organizations. Today, the manner in which most design teams are established seems random and often based on direct contacts between the originators and those involved with implementation. In order to change this situation it is suggested to apply the FAHP method supplemented by ANFIS.

Appropriate research material has to be collected before applying of the presented FAHP based procedure. Correct research tool design is essential. A survey containing a set of questions on determining a list of actual skills and abilities needed in the performance of R\&D projects together with expert opinions defining the "weights" for given data seems in place. However, it should be borne in mind that the format for questions and answers has to reflect the requirements imposed by the application of fuzzy sets in data analysis. Building such a tool and presenting the possibilities for its practical verification shall construe the subject of future papers.

\section{REFERENCES}

[1] E. Daniszewska. „Zastosowanie ANFIS w analizie badań gruntów", in Budownictwo i Architektura, vol. 13(2), 2014, pp. 7-15.

[2] K. Frączkowski. Zarządzanie projektem informatycznym. (...). Wrocław: Oficyna Wydawnicza Politechniki Wrocławskiej, 2003, pp. 18-22.

[3] G. Gierszczewska. Zarzqdzanie strategiczne. Warszawa: WSPiZ, 2000, pp. 18-25.

[4] W. M. Grudzewski and I. Hejduk. „Zarządzanie wiedzą w organizacjach", in E-mentor, vol. 1(8), Warszawa 2005, pp. 46-50.

[5] A. Gryzik, A. Knapińska and A. Tomczyńska. „Zarządzanie projektami badawczo-rozwojowym w sektorze przemysłu", Warszawa: Ośrodek Przetwarzania Informacji - Instytut Badawczy, 2012.

[6] J. Kisielnicki. Zarzqdzanie projektami badawczorozwojowymi. Warszawa: Wolters Kluwer S.A., 2013, pp. 17-61.

[7] P. Lewis James. Project Planning, Scheduling \& Control, 3rd edition. New York: McGraw-Hill, 2001, pp. 28-34.

[8] A. Łuczak. „Ocena ważności czynników strategicznych w gminie wiejskiej z wykorzystaniem rozmytego analitycznego procesu hierarchicznego", in Journal of Agribusiness and Rural Development, vol. 4(6), Poznań 2012, pp. 43-56.

[9] A. Łuczak, F. Wysocki. „Porządkowanie liniowe obiektów z wykorzystaniem rozmytych metod AHP i TOPSIS", in Przeglqd Statystyczny, Zeszyt 1-2, 2011, pp. 4-21. 
[10] P. Łukasik. „Problematyka wyboru strategii zarządzania wiedzą, Studia i prace kolegium zarządzania i finansów", Zeszyt naukowy 99, Warszawa: Szkoła Główna Handlowa w Warszawie, 2010, pp. 121-127.

[11] M. Pawlak. Zarzqdzanie Projektami. Warszawa: Wydawnictwo Naukowe PWN, 2006, pp. 17.

[12] Podręcznik Frascati 2002: Proponowane procedury standardowe dla badań statystycznych $w$ zakresie działalności badawczo-rozwojowej. Warszawa: MNiSW, 2010, pp. 18.
[13] Ch. Schwindt. Resource Allocation in Project Management. Berlin: Springer, 2005, pp. 7 -36.

[14] A. Szeptuch. „Badanie skuteczności metod informatycznych wspomagających zarządzanie wiedzą w uczelni wyższej", in E-mentor, vol. 2(44), 2012, pp. 49-53.

[15] R. Wysocki and R. McGary. Efektywne zarzqdzanie projektami. Gliwice: Helion, 2005, pp. 88-93.

mgr Karol Dąbrowski, mgr Katarzyna Skrzypek

University of Zielona Góra, Faculty of Mechanical Engineering

ul. Prof. Z. Szafrana 4, 65-516 Zielona Góra, POLAND

e-mail: k.dabrowski@iizp.uz.zgora.pl,

k.skrzypek@iizp.uz.zgora.pl 